\title{
EFFICACY OF ANTICHLONERGIC DRUGS IN IDIOPATHIC OVERACTIVE BLADDER.
}

\author{
1. MBBS, FCPS \\ Consultant \\ Department of Urologist \\ Govt Kotkhawaja Saeed Teaching \\ Hospital, Lahore. \\ 2. MBBS \\ Resident Internal Medicine \\ Jinnah Postgraduate Medical \\ Center, Karachi. \\ 3. MBBS \\ Resident Internal Medicine \\ Jinnah Postgraduate Medical \\ Center, Karachi. \\ Correspondence Address: \\ Dr. Muhammad Zahid \\ Department of Urologist \\ Govt Kotkhawaja Saeed \\ Teaching Hospital, Lahore. \\ zahid.urologist@gmail.com \\ Article received on: \\ 12/09/2018 \\ Accepted for publication: \\ 30/12/2018 \\ Received after proof reading: \\ 25/06/2019
}

\section{INTRODUCTION}

Overactive bladder (OAB) may present with symptoms such as urgency (a compelling desire to urinate), frequency (urinating $>7$ times a day), nocturia (urinating more than once in the middle of the night), and urge incontinence (urgency followed by involuntary urinary leakage). There is underlying reduced maximum cystometric capacity which is the volume of bladder at which one feels the need to urinate immediately and cannot delay micturition anymore. Furthermore, detrusor contractions cannot be inhibited voluntarily. When such a person has a coexisting relevant neurological condition which has made detrusor overactive; the condition is termed as neurogenic detrusor over activity. All other cases are termed as idiopathic detrusor over activity.

Symptoms of bladder over activity are common in the community. In a study conducted in 6 countries across Europe, the prevalence of $O A B$ was $16.6 \%$ with frequency as the most common symptom. ${ }^{1}$ In a national survey across United States, the prevalence of OAB in males was

\begin{abstract}
Muhammad Zahid ${ }^{1}$, Faizan Shaukat ${ }^{2}$, Amber Tahir ${ }^{3}$
ABSTRACT... Symptoms of overactive bladder include urgency, frequency, and urge

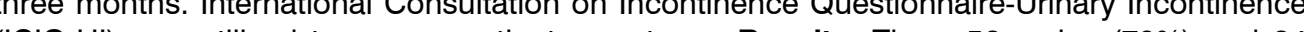
female $(30 \%)$ with mean age of $43 \pm 1.6$ years. Efficacy of solifenacin was found in 61 cases out of 80 patients. On first visit $19(31 \%)$ patients were cured, $17(28 \%)$ on second month follow up and $25(41 \%)$ were cured on third month follow up. Conclusion: Solifenacin has significant role in managing patients with overactive bladder. It has a relatively safe side effect profile.
\end{abstract}

Key words: Muscarinic Receptor Antagonists, Overactive Bladder, Solifenacin Succinate, Urinary Urgency, Urinary Incontinence.
Article Citation: Zahid M, Shaukat F, Tahir A. Efficacy of antichlonergic drugs in idiopathic overactive bladder. Professional Med J 2019; 26(7):1183-1186. DOI: 10.29309/TPMJ/2019.26.07.3795

$16 \%$ and in females $16.9 \% .^{2}$ Studies have also reported that the prevalence of $O A B$ and severity of its symptoms increase with advancing age. ${ }^{1-}$ ${ }^{5}$ around one third of individuals with $O A B$ have urge incontinence. Individuals with neurological conditions such as multiple sclerosis: urinary dysfunction is noted to be more common than neurologically healthy individuals. ${ }^{6}$ whether it be only urgency and frequency or noctiuria and leakage; the overall effects of OAB have profound impact on the quality of life. ${ }^{7}$ It has been noted that many people do not seek medical help for $\mathrm{OAB}$ due to embarrassment and social taboo attached to the condition. ${ }^{1-5}$

The management strategy of $\mathrm{OAB}$ includes pelvic floor strengthening and bladder retaining exercises along with muscarinic receptor antagonists. By inhibiting the muscarinic pathway, anticholinergic drugs block or reduce the severity of detrusor muscle contraction. Muscarinic receptor-3 (M3) selectively act on the smooth muscles; hence selective blockers of $\mathrm{M} 3$ receptors have adequate affect on the detrusor muscle without giving other 
anti-muscarinic affects such as dry mouth or eyes, constipation, and, more rarely, headache or nausea. Various anticholinergic drugs are becoming available. However, their effectiveness is still uncertain. Anticholinergic are still widely used in both primary and secondary care for managing $\mathrm{OAB} .^{8}$

The aim of this study is to study the role of selective anti muscarinic receptor solifenacin succinate in patients with OAB.

\section{METHODOLOGY}

This was a cross sectional study that was carried out at urology department, Kot Khawaja Saeed Hospital, Lahore. Total numbers of 80 patients were enrolled after informed consent. All patients were subjected to $5 \mathrm{mg}$ solifenacin succinate for three months. The symptoms were noted on every follow-up visit (one month apart). International Consultation on Incontinence QuestionnaireUrinary Incontinence (ICIQ-UI) was utilized in this study. Score greater than 6 on was diagnosed as urinary incontinence.

Data was entered and analyzed in computer software SPSS version 20. Quantitative variables like age and clinical presentation was presented in form of frequency and percentages.

\section{RESULTS}

There were total 80 cases; of which 56 (70\%) were male and 24 (30\%) were female cases. The mean $\pm S D$ age of the patients was $43 \pm 1.6$ years. All the patients were subjected to the treatment. It was noted that efficacy was found in 61 cases (76.25\%) out of 80 . Among these, 21 (34.4\%) were women and $40(65.5 \%)$ were men. On first visit $19(31 \%)$ patients were cured, $17(28 \%)$ on second month follow up and 25 (41\%) were cured on third month follow up. (Figure-1).

The side effects profile as reported by the patients is shown in Table-I.

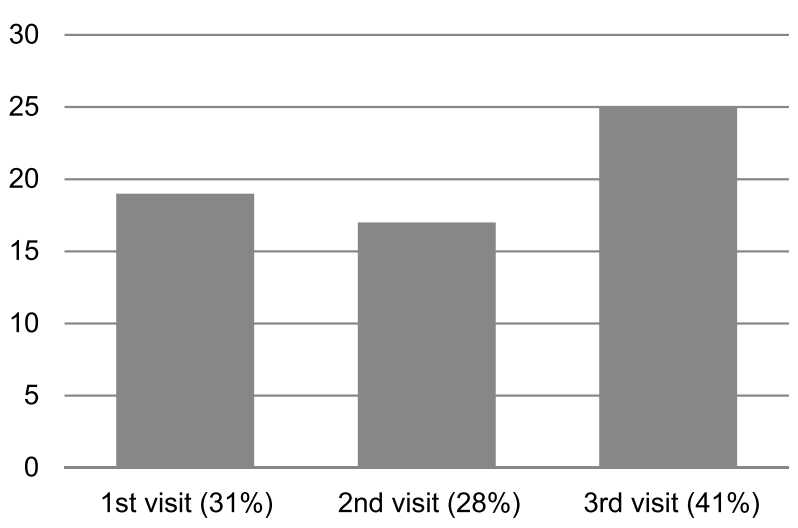

Figure-1. Patient cure per visit by Solifenacin use in overactive bladder

\begin{tabular}{|l|c|}
\hline \multicolumn{1}{|c|}{ Side Effects } & Frequency (\%) \\
\hline Dry Mouth & $16(20 \%)$ \\
\hline Nausea/Dyspepsia & $11(13.75 \%)$ \\
\hline Constipation & $12(15 \%)$ \\
\hline Abdominal Pain & $9(11.25 \%)$ \\
\hline
\end{tabular}

Table-I. Side effects profile of Solifenacin.

\section{DISCUSSION}

Almost two-third of the patients was successfully managed for symptoms of overactive bladder with anticholinergic drug therapy. There were more males. Most of the patients required 3 visits i.e., three months of treatment for producing efficacious results. The most common side effect was dry mouth followed by constipation, nausea/ dyspepsia, and abdominal pain. As compared to Rana et. al., ${ }^{9}$ our sample had a lower incidence of dry mouth but higher incidence of constipation with use of solifenacin.

Solifenacin has its action against muscarinic receptors with selective activity against M3 receptors. M3 receptors mediate cholinergic transmission of exocrine glands and smooth muscle including urinary bladder, ciliary muscle and salivary glands. ${ }^{10}$ Furthermore, solifenacin has shown greater selectivity for bladder smooth muscle than salivary glands. ${ }^{10}$

Various controlled trials have been conducted to support the efficacy of solifenacin $5 \mathrm{mg}$ and $10 \mathrm{mg}$ once daily in significant improvement of bothersome symptoms of overactive bladder. ${ }^{11-13}$ 
Urinary urgency, frequency, and incontinence have always been the source of embarrassment, annoyance, and a hassle to the patients. These problems result in patient anxiety, frustration, and social fear. Patients with these symptoms of OAB have been coping through behavioral changes such as reducing daily fluid intake, avoiding longer outdoor trips, travelling only to places where they are sure about restroom availability, wearing incontinence pads and adult diapers, and carrying extra pair of clothes with them in case of a leak episode. All of these factors cause significant anxiety and decrease quality of life of these patients. ${ }^{14}$ Solifenacin with its selective activity against urinary bladder muscles has significantly improved the quality of life of these patients.

In conclusion, solifenacin has great potential for patients with symptoms of OAB. It is a relatively safe drug with selective activity against muscarinic receptor subtype $M 3$, hence, reduced side effect profile. Treatment of patients with anticholinergic drug such as solifenacin has role in improving quality of life of people suffering from $O A B$.

\section{Copyright@ 30 Dec, 2018.}

\section{REFERENCES}

1. Milsom I, Abrams P, Cardozo L, Roberts RG, Thuroff J, Wein AJ. How widespread are the symptoms of an overactive bladder and how are they managed? A population-based prevalence study. Br J Urol Int 2001; 87: 760-66.

2. Stewart WF, Corey R, Herzog AR, Wein A, Norton PA, Payne C. et al. Int Urogynecol J Pelvic Floor Dysfunct 2001; 12 : S6.

3. Brown JS, Grady D, Ouslander JG, Herzog AR, Varner RE, Posner SF. Prevalence of urinary incontinence and associated risk faders in postmenopausal women. Heart and Estrogen/Progestin Replacement Study (HERS) Research Group. Obstet Gynecol 1999; 94: 66-70.

4. Moller LA, Lose G., Jorgensen T. The prevalence and bothersomeness of lower urinary tract Symptoms in women 40-60 years of age. Acta Obstet Gynecol Scand 2000; 79: 298-305.
5. Ueda T, Tamaki M, Kageyama 8, Yoshimura N, Yoshida 0 . Urinary incontinence among community-dwelling people aged $\mathbf{4 0}$ years or older in Japan: Prevalence, risk factors, knowledge and self-perception. Int $\mathrm{J}$ Urol 2000; 7: 95-103.

6. Hennessey A, Robertson NP, Swingler R, Compston DA. Urinary, faecal and sexual dysfunction in patients with multiple sclerosis. J Neurol 1999; 246: 1027-32.

7. Jackson S. The patient with an overactive bladdersymptoms and quality of life issues. Urology 1997; 50 (suppl 6A): 18-22.

8. Kobelt G. Economic considerations and outcome measurement in urge incontinence. Urology 1997; 50 (suppl 6A): 100-7.

9. Rana M, Mobusher I. Comparison of Side Effects of Tolterodine and Solifenacinsucinate in Patients with Urinary Incontinence. Pakistan Journal of Medical \& Health Sciences. 2016 Jan 1; 10(1):176-9.

10. Wyndaele JJ. Solifenacin: A new drug for the treatment of overactive bladder and detrusor over activity. Therapy. 2006 Jul 1; 3(4):485-94.

11. Wagg A, Wyndaele JJ, Sieber P. Efficacy and tolerability of solifenacin in elderly subjects with overactive bladder syndrome: a pooled analysis. The American journal of geriatric pharmacotherapy. 2006 Mar 1; 4(1):14-24.

12. Vardy MD, Mitcheson HD, Samuels TA, Wegenke JD, Forero $\square$ Schwanhaeuser S, Marshall TS, He W. Effects of solifenacin on overactive bladder symptoms, symptom bother and other patient-reported outcomes: Results from VIBRANT-a double-blind, placebo $\square$ controlled trial. International journal of clinical practice. 2009 Dec; 63(12):1702-14.

13. Cardozo L, Lisec M, Millard R, Kuzmin I, Drogendijk TE, Huang M, Ridder AM. Randomized, doubleblind placebo controlled trial of the once daily antimuscarinic agent solifenacin succinate in patients with overactive bladder. The Journal of urology. 2004 Nov 1; 172(5):1919-24.

14. Abrams P, Kelleher CJ, Kerr LA, Rogers RG. Overactive bladder significantly affects quality of life. Am J Manag Care. 2000 Jul 1; 6(11 Suppl):S580-90.

15. Kelleher CJ, Cardozo L, Chapple CR, Haab F, Ridder AM. Improved quality of life in patients with overactive bladder symptoms treated with solifenacin. BJU international. 2005 Jan; 95(1):81-5. 


\begin{tabular}{|c|l|l|l|}
\hline \multicolumn{3}{|c}{ AUTHORSHIP AND CONTRIBUTION DECLARATION } \\
\hline Sr. \# & Author-s Full Name & \multicolumn{1}{|c|}{ Contribution to the paper } & Author=s Signature \\
\hline 1 & Muhammad Zahid & $\begin{array}{l}\text { Research idea an methodology } \\
\text { design, construction of questionnaire, } \\
\text { manuscript preparation, Final } \\
\text { responsibility of the study. } \\
\text { Data collection and data analysis, } \\
\text { results preparation, manuscript writing. } \\
\text { Data collection, literature search, } \\
\text { manuscript writing. }\end{array}$ \\
\hline 3 & Amber Tahir & Faizan Shaukat & \\
\hline
\end{tabular}

